$15^{\text {th }}$ International Conference on

AEROSPACE SCIENCES \& AVIATION TECHNOLOGY,

$\boldsymbol{A S A T}$ - 15 - May 28 - 30, 2013, Email: asat@mtc.edu.eg,

Military Technical College, Kobry Elkobbah, Cairo, Egypt,

Tel: +(202) 24025292 -24036138, Fax: +(202) 22621908



\title{
Effect of Tetracycline in Improving Composite Propellant Pot Life
}

\author{
N. M. Elamin", M. H. M. Abuuznien ${ }^{\dagger}$, B. M. Sidig ${ }^{\ddagger}$
}

\begin{abstract}
Propellant mixing and casting processes are the most complex and important operations in composite propellants manufacturing. They are affected by the rheological properties of the propellant. Casting process of composite propellants is influenced directly by its pot life. The short pot life of the propellant formulations can result in low reliability and increase the processing cost [1]. The propellant pot life is defined as the time available for accomplishing the processing steps of mixing and casting propellant before the propellant loses its fluid nature [2]. Different methods have been proposed for improving composite propellant process by extending its pot life using some affected chemical materials. This work concentrated on using the well-known antibiotic (tetracycline) to achieve this objective. When tetracycline added to the propellant formulation, the pot life was extended by a considerable time ranged between two and four hours. This extension referred to the solution which tetracycline offered to the problem that occurs from using transition metal materials (ferrocene compounds) in the propellant slurry to improve the burning rate. This addition of ferrocene compounds results in accelerating the curing reaction and so, shorten the pot life of the slurry. Tetracycline has good possibilities for metal complex formation and its activity depends on its metal binding function [3]. Moreover, tetracycline is cheap and available which let its use easier than other materials used for the same purpose. The results obtained from this work can help the manufacturer in filling big rocket motors by use of small mixers by applying the above method of extending the propellant pot life.
\end{abstract}

Keywords: Composite propellant, casting process, propellant curing, pot life, tetracyline.

\section{Nomenclature}

$\begin{array}{ll}\text { AP } & \text { Ammonium Perchlorate } \\ \text { DDI } & \text { 3,2, Dioxynosine Diisocynite } \\ \text { HTPB } & \text { Hydroxy-Terminated Poly-butadiene } \\ \text { IPDI } & \text { Iso Pheron Di Isocynate } \\ \text { PDI } & \text { Pheron Di Isocynate } \\ \text { TDI } & \text { Toluene Diisocyanate } \\ \text { TC } & \text { Tetracycline } \\ \sigma_{\mathrm{m}} & \text { Maximum Tensile Strength } \\ \eta_{\mathrm{P}} & \text { Propellant Viscosity }\end{array}$

Assistance Professor, Chemical Engineering Dep., Karary University, Sudan, hoama10@yahoo.com

$\dagger \quad$ Associate Professor, Head of Department of Chemical Engineering, Karary University, Sudan, abuuznien77@yahoo.com

* Associate Professor, Chemical Engineering Dep., Karary University, Sudan. 


$\begin{array}{ll}\mathrm{F}(\mathrm{N}) & \text { Thrust } \\ \mathrm{I}_{\mathrm{sp}}(\mathrm{m} / \mathrm{s}) & \text { Specific Impulse } \\ \mathrm{P}_{\mathrm{b}}(\mathrm{MPa}) & \text { Prssure } \\ \mathrm{r}_{\mathrm{b}}(\mathrm{m} / \mathrm{s}) & \text { Rate of Burning } \\ \mathrm{C}^{*}(\mathrm{~m} / \mathrm{s}) & \text { Charcteristic Velocity }\end{array}$

\section{Introduction}

Composite propellants often contain transition metal compounds as burning rates modifiers. These additives accelerate the curing reaction after the addition of the curing agent during mixing process. Different methods have been proposed to extend the pot life. Based on the process, the addition of some chemical materials affect the pot life of the propellant slurry, some of them decrease and others increase the pot life, but, any of these materials used according to the process requirements and cannot be removed. The "pot life" of the propellant slurry can be defined by many different terms. It is defined as the period of time during which a thermosetting plastic composition remains suitable for its intended use after mixing with a reaction-initiating agent. It is also called the working life or the usable life. Sometimes, It is defined as the time available for accomplishing the processing steps of mixing and casting propellant before the propellant loses its fluid nature.[2] The pot life is measured by the degree of the propellant viscosity. Viscosity is recognized as a property of a liquid, which was a measure of its resistance to flow, so that high viscosity liquids flow slowly and low viscosity liquids flow quickly. Pot life and the propellant viscosity are related reversly. The viscosity play an important role in determining the velocity field, which varies from one fluid to another dictated by the viscosity function $[4,5]$.

Many inventions were carried out described different methods for increasing the pot life of composite propellants. A research paper analyzed the viscosity and mechanical characteristics based on three different types of curing agents including isocyanate's groups: DDI, IPDI and TDI. It was shown that the largest change of viscosity throughout measuring occurred in DDI propellants and for IPDI and TDI propellants three times respectively. However, for heavy formulations (86 mass percentage solids and more), DDI propellants have the highest viscosity and therefore it can be concluded that this curing agent is not suitable for application in case of extremely heavy formulations [6].

A new series of composite propellant compositions, have been developed with a mixture of toluene diisocyanate (TDI) and isophorone diisocyanate (IPDI) to study their effect on processability, mechanical and ballistic properties of the compositions. The data indicated that the compositions based on bicurative mixture have a pot life of 7-8 hours, viscosity build up is from 13280 to 14080 poise after 4 hours, and the smooth processability of the slurry is enhanced [7]. The pot life of TDI cured propellant is about 4-5 hours. IPDI is more preferred than TDI mainly on its slow reactivity, resulting in much extended pot life i.e. 15-18 hours as well as low toxicity. [8, 9]

Trioctylphosphine oxide and tributylphosphine oxide are representative of phosphine oxide compounds, which are utilized in isocyanate curable composite propellant compositions to extend usable pot life required for mixing and processing of the specified compositions. The compositions are comprised of a binder of hydroxy terminated liquid polymer systems, optional selected plasticizers, optional metal fuel, and the inorganic oxidizer, ammonium perchlorate that is substantially of very fine particle size [10]. 
Other methods were described in some papers for extending the propellant pot life such as, treating and removing of ironic metals impurities[11], changing the nature of solid oxidizer [12], addition of dicarboxylic acids such as maleic and oic acids[13], addition of $\mathrm{m}$ tetramethylxylene diisocyanate (m-TMXDI) [14] ,using polyols and polyamines [15]. using chelating agents such as the condensation products of salicylaldehyde with aliphatic di- and polyamines and with o-aminophenols [16], incorporating into the propellant composition mix of organo-aluminum compound, tri (N-nitrosophenyl hydroxyl aluminum) [17], improving the mixing temperature and time $[18,19,20]$, calcining the burning rate catalyst at high temperatures [21], improving the resistance of the binder towards oxidative attack using selected compound di-thio-di-propionate [22], addition of near critical liquid carbon dioxide [23], using of glycerin [24], adjusting the rheological properties of the propellant slurry [25,26], using chain extenders [25,27], adjusting the propellant hydroxyl value [28,29], delaying the addition of the curing agent in the mixing process [30] and others.

Some papers described the use of a well-known antibiotic (oxytetracycline) to increase the propellant pot life by virtue of its complex forming property and its structure providing good possibility for metal complex formation and the antibiotic activity is considered to depend on its metal binding function. By adding oxytetracyclene, this problem can be easily eliminated and about the same pot lives are obtained as for propellants with no iron compounds. Pot lives have been successfully extended up to 2 to 3 hours. Mechanical properties of oxytetracycline containing propellants are better than propellants without oxytetracyline. [3, 31,32].

\section{Materials and Equipment}

For the practical of this paper, most of the manufacturing and testing processes of composite propellants were applied, such as preparation of raw materials, mixing process, casting process, curing process, tensile test, viscosity measurement, ground static test .. etc. These processes were carried out using many types of equipment and processing systems such as ammonium perchlorate crusher, balances for weighing, small mixer, casting system device, curing oven, viscometer, mechanical tester, hardness testing device and ground static test. Some of those equipment and systems are shown in figures 5 to 9 at the end of this paper.

\section{Experimental Work}

The procedure used in this work was the addition of different percentages of small amount of the antibiotic (Oxytetracycline TC) to the standard mixing formulation. Four experiments were carried out for mixing the binder system; one of them was a standard mixing and the others were done with addition of antibiotic (oxy-tetracycline) by $0.05 \%, 0.1 \%$ and $0.15 \%$ from the total amount of the propellant slurry respectively. the changes of the viscosity build up in each experiment were noticed and recorded. Table (1) represents the results of the viscosity build up during experiments on the binder system for all experiments and figure (1) represents the same results graphically. The addition of $0.1 \%$ of tetracycline has shown to be the best one in the extension of the pot life. This percentage is chosen to apply in the whole slurry of the propellant. Three experiments for the above chosen percentage (1\%), were carried out; each experiment has a standard mixings for comparison. The standard mixings have known ranges for the values of the mechanical properties, which are shown in table (2) and standard ranges for the performance properties, which are shown in table (3). 


\section{Results and Discussion}

Results of the viscosity build up and the properties of the propellant, for the three experiments were obtained and compared with the readings of the standard mixing of each.

Results of experiment No. 1 are shown in tables (4, 5 and 6) and figure 2. Results of experiment No. 2 are shown in tables (7, 8 and 9) and figure 3. Results of experiment No. 3 are shown in tables (10, 11 and 12) and figure 4.

Application of this method in the binder system indicated that, the addition of tetracycline resulted in a significant effect on the viscosity build up. Slurry became less viscous and pot life was extended for a considerable time. It was also noticed that, the results obtained from the addition of $0.1 \%$ tetracycline are the best results for pot life extension. The addition of $0.05 \%$ has a small effect, while the addition of $0.15 \%$ TC affect the pot life reversely. This result can be referred to the big amount of the antibiotic added, which increased the solid loadings and then, shorten the pot life. The obtained results proved that, there is a limit for adding the antibiotic to the propellant slurry for obtaining the satisfactory results. When this method applied in the whole slurry of the propellant, the pot life extended by a considerable time range between two to three hours. This extension referred to the solution which tetracycline offered to the problem (reffer to the abstract and the introduction of this paper).

\section{Conclusion}

It can be concluded that, tetracycline can result in a significant extension of the propellant pot life without effect on the mechanical and performance properties. The amount of tetracycline used, must not be too big, in order to avoid undesired effects in the pot life or in the mechanical and performance properties. There are limits for using this material.

\section{References}

[1] Carlton L. H., " Solid Propellant Processing Factors in Rocket Motor Design" NASA SP-8075, October 1971

[2] Cocksee, M.T. and Allen, H.C. "Extension of Pot Life of HTPB Composite Propellants by Phosphine Oxides" US Patent 3974004, Aug. 1976.

[3] Hussain. S. Z. "Development of Energetic HTPB - Based Composite Propellant and Use of Oxytetracycline Antibiotic" A. Q. Khan Research laboratories, Pakistan,1996, Pages 17-26.

[4] Barnes, H. A. "A Handbook of Elementary Rheology" Institute of Non-Newtonian Fluid Mechanics, University of Wales, Aberystwyth, 2000.

[5] Glassman, I. and Sawyer, R.F. "The Performance of Chemical Propellants" AGARD No. 129, Athens, Greek, January 1970.

[6] Rodić V. and Mirjana P., (The effect of curing agents on solid composite rocket propellant Characteristics) Scientific-Technical Review, Vol.LV, No.1, 2005, UDK: 621.45.07-6:662.769, COSATI: 21-09.

[7] Jawalker, N., Mehilal R. Kurva, and Bhattacharya B. "Influence of Bicurative on Processibility of Composite Propellant" Defence Science Journal, Vol. 57, No. 5, September 2007, pp 669-675.

[8] Willacker, J.F., Edwards, G.R. and Phillips, C.E. "IUS Solid Rocket Motor Useful Life Extension Programme" JANAF Propulsion Meeting, Vol. 480(1), CPTA, Dec. 1987, pp. 341-50. 
[9] Butts, P.G; Hammod, R.N. \& Shdo, J. "IUS Propellant Development and Qualification" JANAF Propulsion Meeting, Vol. 370(1), CPTA, Feb. 1987.

[10] Mahanta, A.K., Goyal, M. and Pathak, D.D. "Rheokinetic Analysis of Hydroxy Terminated Polybutadiene Based Solid Propellant Slurry" E-Journal of Chemistry, Vol. 7, No. 1, 2010, Pages 171-179

[11] Rudy, T. P. and Nakagawa, T. W., "Purification of combustion catalysts and solid propellant compositions containing the same" United States Patent Number: 4, 166, 045, 1979.

[12] Kristofferson, C. E. Fisher, D. G. Bell, F. H. and Wagner, W. F. "Solvent-free preparation of gun propellant formulations" US Patent Number 4650617; March 1987.

[13] Ducote, M. E. "Prevention of unwanted cure catalysis in isocyanate cured binders" United States Patent Number 4597811; July 1985.

[14] Ducote, M. E., "TMXDI, Curing Agent for Hydroxy Terminated Propellant Binders" United States Patent 4913753, September 1989.

[15] Babjak, J. R. and Yokoyama, T. W., "Method for Extending the Pot-life of Polyolpolyisocyanate Mixtures" United States Patent 5157100.

[16] Nakagawa, T. W. and. Rudy, T. P "Stabilizers for solid propellant binders"; US Patent No. 4260437, April 1983.

[17] Sayles, D. C., "Method of Controlling the Increase in Pot Life of Propellants During Processing" United States Patent 5112417, 05/12/1992

[18] Iwama, K. A. and Fukuda, T. "On the Adhesion between HTPB Fuel Binder and Ammonium Perchlorate. Performance of Bonding Agent" Journal of Propellants, Explosives and Pyrotechnics, Vol. 10, No. 6, 1985, pages 176-180.

[19] Muthiah, R. and Krishnamurty, V. N. "Rheology of HTPB Propellant: Development of Generalized Correlation and Evaluation of Pot life" Propellants, Explosives, Pyrotechnics, Vol. 21, 1996, Pages 186-192.

[20] Muthiah, R., Krishnamurthy, V. N. and Gupta, B. R. "Effect of temperature on the rheological behavior of hydroxyl terminated polybutadiene propellant slurry" Polymer Engineering \& Science, Volume 31, Issue 2, January 1991, Pages 61-66.

[21] Hamner, J. W. Hightower, J. O. and Rector, C. M. "Technique for improving processability of certain composite propellants by calcining the iron oxide burning rate catalyst" US Patent No. 4120709, April 1973.

[22] Mastrolia, et. a.1 "Processing Aids for Hydroxy-Terminated Poly Butadiene" US Patent No. 3801385, April 1974.

[23] Melvin, W.S. and Mitchell, P.H. "Processing of High Solids Propellant" US patent No. 3022149, May 1987.

[24] Makoto K., "From Cross-linking to Plasticization - Characterization of Glycerin/HTPB Blends" Propellants, Explosives, Pyrotechnics. Volume 34, Issue 5, pages 436-443, October 2009.

[25] Bandgar, B. M., Krishnamurthy,V. N., Mukundar, T. and Sharma, K. C. "Mathematical Modeling of Rheological Properties of Hydroxyl-Terminated Polybutadiene Binder and Dioctyl Adipate Plasticizer" Journal of applied polymer science, Vol. 85, 2002, India, Pages $1002-1007$.

[26] Sekkar, V. V., S. and Ninan, K. N. "Rheokinetic Studies on the Formation of Urethane Networks Based on Hydroxyl Terminated Polybutadiene" European Polymer Jurnal, Vol. 38, 2002, Pages (169 - 178).

[27] Ramesh, S., R,. and Radhakrishnan, G. "Chain Extended Polyurethanes Synthesis and Characterization" Polymer International, Vol. 25, 1991, Pages 253-256. 
[28] Manjari, R. Joseph, V. C. Pandureng, L.P. and Sriram, T. "Structure-Properly Relationship of HTPB-Based Propellants: Effect of Hydroxyl Value of HTPB Resin" Jurnal of Applied Polymer Science, Vol. 48, 271-278, 1993.

[29] Manjari, R,. Somasundaran, U.I., Joseph, V. C. and Sriram, T. "Structure-Properly Relationship of HTPB-Based Propellants: Formulation Tailoring for Better Mechanical Properties" Journal of Applied Polymer Science, Vol. 48, 1993, pages 279-289.

[30] Amin. N. M. "Improving the pot life of HTPB/AP composite propellant slurry" a PhD thesis to Karary University, Sudan, December 2012.

[31] Tokui, H. and Iwama, A., "Pot Life Problem and its measure with a reduced smoke propellant production" Propellants, Explosives, Pyrotechnics, Volume 16, Issue 3, June 1991, pages 105-109.

[32] Sanden, R. "Method for Extension of Pot Life in Curing Reactions" US Patent No. 4493916, Jan 1985.

Table 1 Viscosity build up with time for the binder system for different percentages of oxy-tetracycline

\begin{tabular}{c|c|c|c|c}
\hline \hline \multirow{2}{*}{$\begin{array}{c}\text { Time } \\
\text { readings (h) }\end{array}$} & \multicolumn{4}{|c}{ Viscosity (poise) } \\
\cline { 2 - 5 } & $\begin{array}{c}\text { Standard } \\
\text { mixing }\end{array}$ & $\begin{array}{c}\text { Addition of } \\
0.05 \% \text { TC }\end{array}$ & $\begin{array}{c}\text { Addition of } \\
0.1 \% \text { TC }\end{array}$ & $\begin{array}{c}\text { Addition of } \\
0.15 \% \text { TC }\end{array}$ \\
\hline 1 & 100 & 70 & 50 & 70 \\
\hline 2 & 150 & 110 & 75 & 110 \\
\hline 3 & 210 & 150 & 100 & 150 \\
\hline 4 & 290 & 180 & 120 & 200 \\
\hline 5 & 370 & 220 & 150 & 250 \\
\hline 6 & 460 & 260 & 220 & 310 \\
\hline 7 & 560 & 310 & 260 & 380 \\
\hline 8 & 640 & 370 & 310 & 460 \\
\hline \hline
\end{tabular}

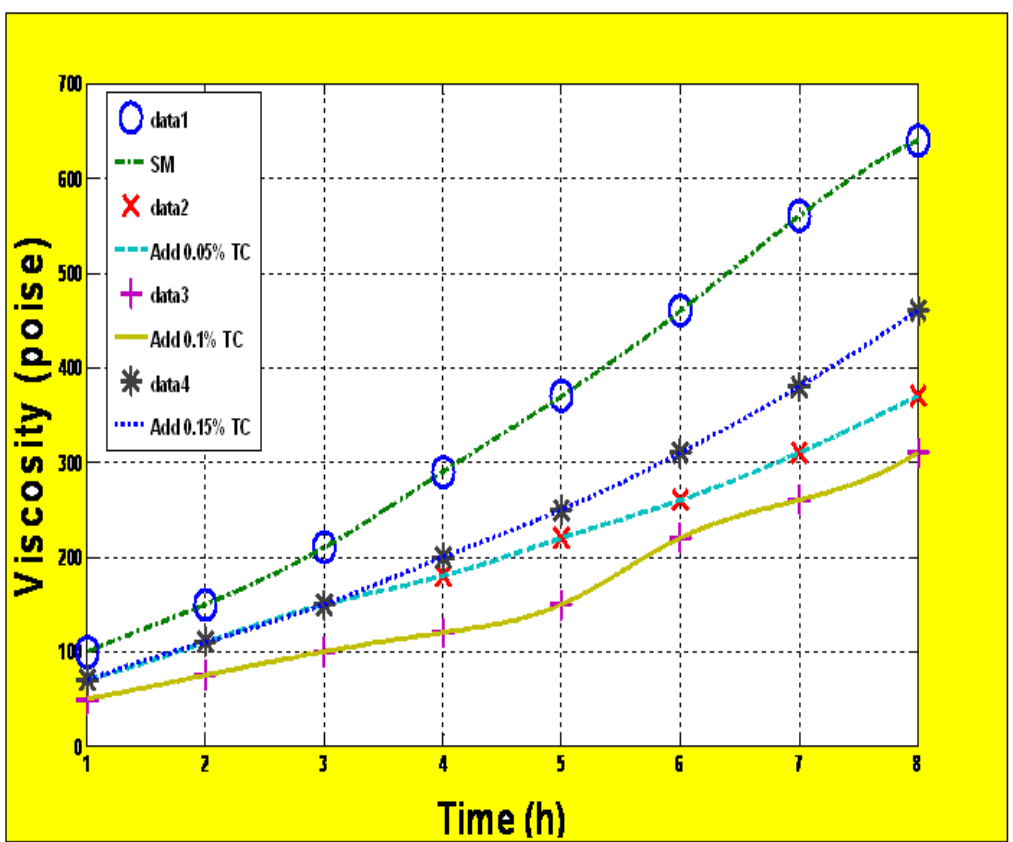

Fig. 1 Viscosity build up vs. time of the binder system for different percentages of oxy-tetracycline 
Table 2 Standard ranges for the mechanical properties

\begin{tabular}{c|c|c|c|c}
\hline \hline Property & Tensile strength & Extensibility & Density & Hardness \\
\hline Unit & $\mathrm{Mpa}$ & $\%$ & $\mathrm{gm} / \mathrm{cm}^{3}$ & $\mathrm{Mpa}$ \\
\hline Range & $0.75-1.2$ & $35-45$ & $1.75-1.77$ & $45-65$ \\
\hline \hline
\end{tabular}

Table 3 Standard ranges for the performance properties

\begin{tabular}{c|c|c|c|c|c|c}
\hline \hline Property & $\begin{array}{c}\text { Burning } \\
\text { Time }\end{array}$ & $\begin{array}{c}\text { Burning } \\
\text { Rate }\end{array}$ & $\begin{array}{c}\text { Average } \\
\text { Pressure }\end{array}$ & $\begin{array}{c}\text { Average } \\
\text { Thrust }\end{array}$ & $\begin{array}{c}\text { Characteristic } \\
\text { Velosicty }\end{array}$ & $\begin{array}{c}\text { Specific } \\
\text { Impulse }\end{array}$ \\
\hline Unit & $\mathrm{S}$ & $\mathrm{m} / \mathrm{s}$ & $\mathrm{MPa}$ & $\mathrm{kN}$ & $\mathrm{m} / \mathrm{s}$ & N.s/kg \\
\hline Range & $0.8-1.2$ & $16-19$ & $4-6$ & $3-5$ & $1300-1600$ & $2000-2400$ \\
\hline \hline
\end{tabular}

Table 4 Viscosity build up with time for experiment No. 1

\begin{tabular}{c|c|c}
\hline \hline \multirow{2}{*}{$\begin{array}{c}\text { Time readings } \\
(\mathrm{h})\end{array}$} & \multicolumn{2}{|c}{ Viscosity (poise) } \\
\cline { 2 - 3 } & Std mixing & $0.1 \% \mathrm{TC}$ \\
\hline 1 & 2,778 & 2,207 \\
\hline 2 & 2,825 & 2,371 \\
\hline 3 & 3,766 & 2,691 \\
\hline 4 & 5,382 & 3,533 \\
\hline 5 & 6,719 & 4,492 \\
\hline 6 & 9,913 & 5,661 \\
\hline 7 & 12,897 & 7,236 \\
\hline 8 & - & 8,945 \\
\hline 9 & - & 10,952 \\
\hline 10 & - & 13,089 \\
\hline \hline
\end{tabular}

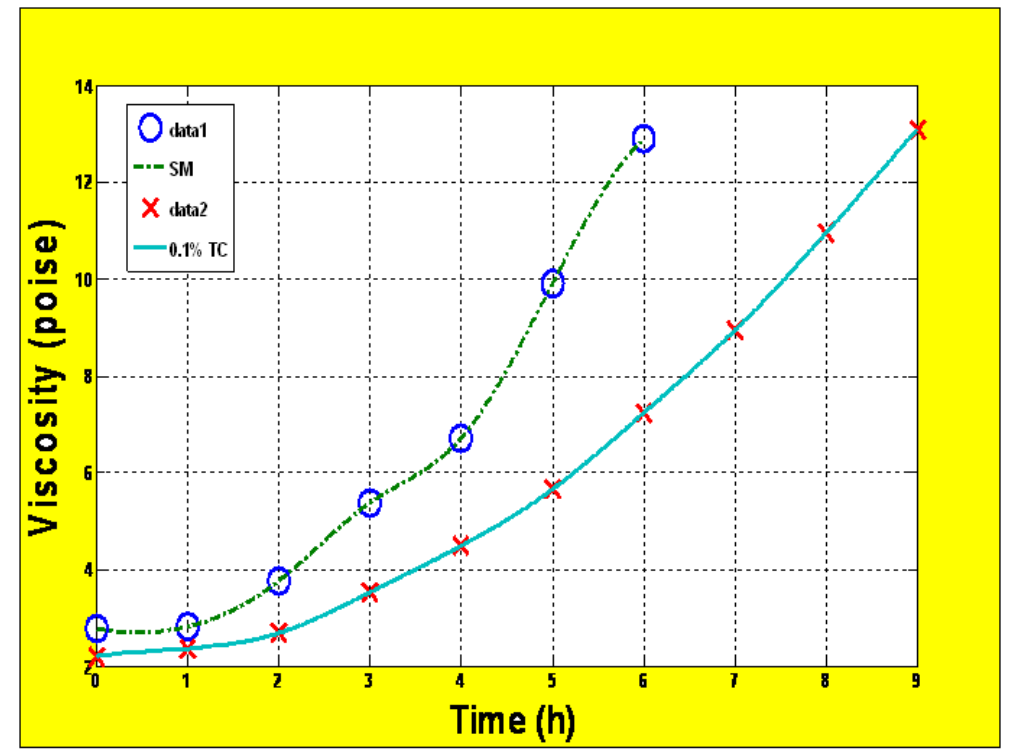

Fig. 2 Viscosity build up vs. time for experiment No. 1 
Table 5 Performance properties for experiment No. 1

\begin{tabular}{l|c|c|c}
\hline \multicolumn{1}{c|}{ Property } & Unit & Std mixing & $0.1 \%$ TC \\
\hline Burning time & $\mathrm{s}$ & 0.896 & 0.929 \\
\hline Average pressure & $\mathrm{MPa}$ & 5.605 & 5.205 \\
\hline Characteristic velocity & $\mathrm{m} / \mathrm{s}$ & 1391 & 1419 \\
\hline Burning rate & $\mathrm{mm} / \mathrm{s}$ & 17.75 & 17.47 \\
\hline Average thrust & $\mathrm{kN}$ & 3.781 & 5.253 \\
\hline Specific impulse & $\mathrm{N} . \mathrm{S} / \mathrm{kg}$ & 2237 & 2332 \\
\hline \hline
\end{tabular}

Table 6 Mechanical properties for experiment No. 1

\begin{tabular}{l|c|c|c}
\hline \multicolumn{1}{c|}{ Property } & Unit & Std mixing & $0.1 \% \mathrm{TC}$ \\
\hline Tensile strength & $\mathrm{kN}$ & 0.844 & 0.806 \\
\hline Extensibility & $\%$ & 36.892 & 42 \\
\hline Hardness & $\mathrm{kN}$ & 50 & 48 \\
\hline Density & $\mathrm{g} / \mathrm{cm}^{3}$ & 1.76 & 1.76 \\
\hline \hline
\end{tabular}

Table 7 Viscosity build up with time for experiment No. 2

\begin{tabular}{c|c|c}
\hline \hline \multirow{2}{*}{$\begin{array}{c}\text { Time readings } \\
(\mathrm{h})\end{array}$} & \multicolumn{2}{|c}{ Viscosity (poise) } \\
\cline { 2 - 3 } & Std mixing & $0.1 \% \mathrm{TC}$ \\
\hline 1 & 2,778 & 2,407 \\
\hline 2 & 2,825 & 2,534 \\
\hline 3 & 3,766 & 2,898 \\
\hline 4 & 5,382 & 3,636 \\
\hline 5 & 6,719 & 4,699 \\
\hline 6 & 9,913 & 6,103 \\
\hline 7 & 12,897 & 8,362 \\
\hline 8 & - & 10,708 \\
\hline 9 & - & 13,185 \\
\hline 10 & - & 15,653 \\
\hline
\end{tabular}

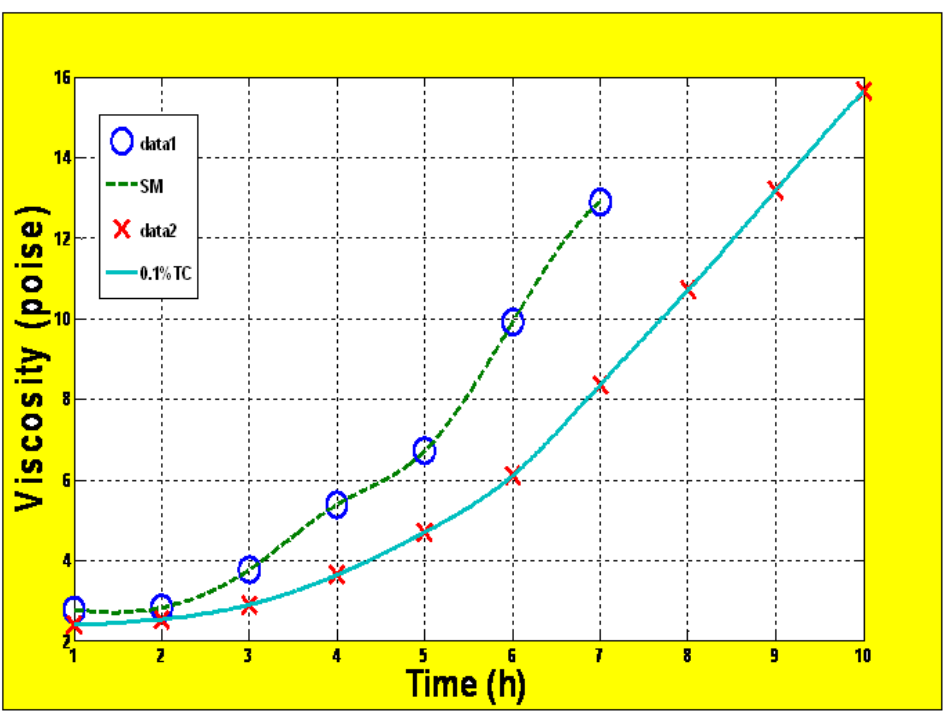

Fig. 3 Viscosity build up vs. time of experiment No. 2 
Table 8 Performance properties for experiment No. 2

\begin{tabular}{l|c|c|c}
\hline \hline \multicolumn{1}{c|}{ Property } & Unit & Std mixing & $0.1 \% \mathrm{TC}$ \\
\hline Burning time & $\mathrm{s}$ & 0.896 & 0.936 \\
\hline Average pressure & $\mathrm{MPa}$ & 5.605 & 5.452 \\
\hline Characteristic velocity & $\mathrm{m} / \mathrm{s}$ & 1391 & 1410 \\
\hline Burning rate & $\mathrm{mm} / \mathrm{s}$ & 17.75 & 17.15 \\
\hline Average thrust & $\mathrm{kN}$ & 3.781 & 3.537 \\
\hline Specific impulse & $\mathrm{N} . \mathrm{S} / \mathrm{kg}$ & 2237.6 & 2175 \\
\hline \hline
\end{tabular}

Table 9 Mechanical properties for experiment No. 2

\begin{tabular}{l|c|c|c}
\hline \hline \multicolumn{1}{c|}{ Property } & Unit & Std mixing & $0.1 \% \mathrm{TC}$ \\
\hline Tensile strength & $\mathrm{kN}$ & 0.844 & 0.801 \\
\hline Extensibility & $\%$ & 36.892 & 40.152 \\
\hline hardness & $\mathrm{kN}$ & 50 & 48 \\
\hline density & $\mathrm{g} / \mathrm{cm}^{3}$ & 1.76 & 1.76 \\
\hline \hline
\end{tabular}

Table 10 Viscosity build up with time for experiment No. 3

\begin{tabular}{c|c|c}
\hline \hline \multirow{2}{*}{$\begin{array}{c}\text { Time Readings } \\
(\mathrm{h})\end{array}$} & \multicolumn{2}{|c}{ Viscosity (poise) } \\
\cline { 2 - 3 } & Std mixing & $0.1 \% \mathrm{TC}$ \\
\hline 1 & 2,778 & 2,741 \\
\hline 2 & 2,825 & 2,801 \\
\hline 3 & 3,766 & 3,026 \\
\hline 4 & 5,382 & 3,844 \\
\hline 5 & 6,719 & 4,986 \\
\hline 6 & 9,913 & 6,027 \\
\hline 7 & 12,897 & 8,095 \\
\hline 8 & - & 10,265 \\
\hline 9 & - & 12,580 \\
\hline 10 & - & 14,927 \\
\hline \hline
\end{tabular}

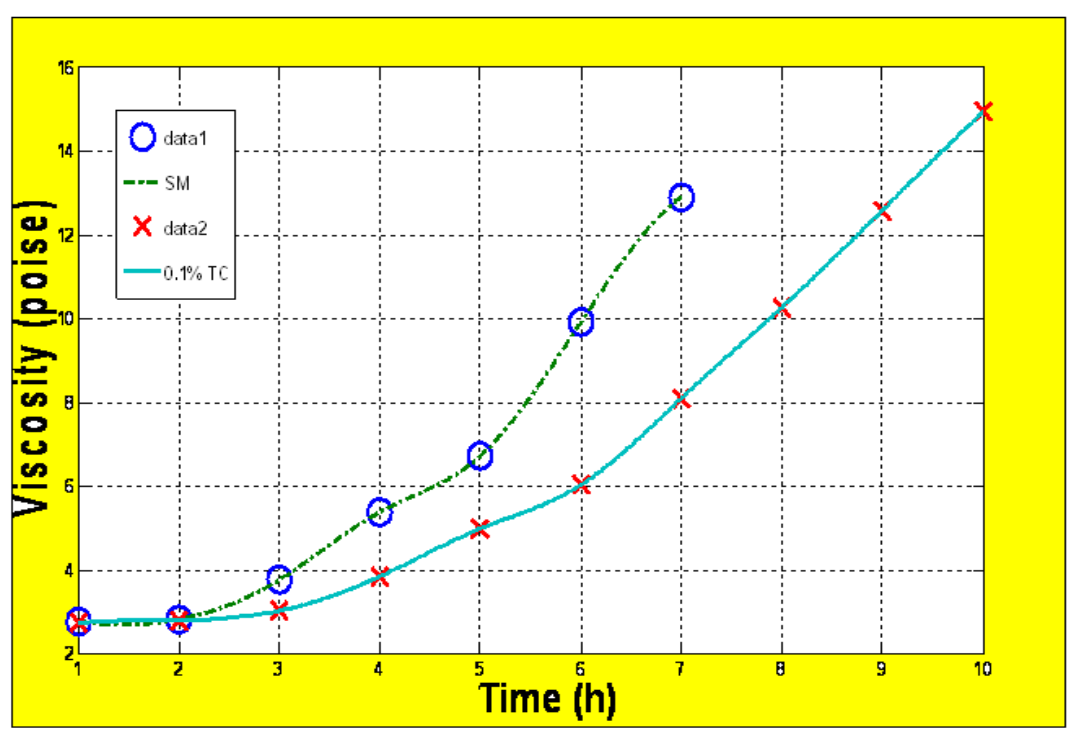

Fig. 4 Viscosity build-up vs. time for experiment No. 3 
Table 11 Performance properties for experiment No. 3

\begin{tabular}{l|c|c|c}
\hline \hline \multicolumn{1}{c|}{ Property } & Unit & Std mixing & $0.1 \% \mathrm{TC}$ \\
\hline Burning time & $\mathrm{S}$ & 0.896 & 0.916 \\
\hline Average pressure & $\mathrm{MPa}$ & 5.605 & 5.497 \\
\hline Characteristic velocity & $\mathrm{m} / \mathrm{s}$ & 1391 & 1426 \\
\hline Burning rate & $\mathrm{mm} / \mathrm{s}$ & 17.75 & 17.45 \\
\hline Average thrust & $\mathrm{kN}$ & 3.781 & 3.295 \\
\hline Specific impulse & $\mathrm{N} . \mathrm{S} / \mathrm{kg}$ & 2237 & 2338 \\
\hline \hline
\end{tabular}

Table 12 Mechanical properties for experiment No. 3 in method No. 3

\begin{tabular}{l|c|c|c}
\hline \hline \multicolumn{1}{c|}{ Property } & Unit & Std mixing & $0.1 \% \mathrm{TC}$ \\
\hline Tensile strength & $\mathrm{kN}$ & 0.844 & 0.834 \\
\hline Extensibility & $\%$ & 36.892 & 39.89 \\
\hline Hardness & $\mathrm{kN}$ & 50 & 49 \\
\hline Density & $\mathrm{g} / \mathrm{cm}^{3}$ & 1.76 & 1.75 \\
\hline \hline
\end{tabular}

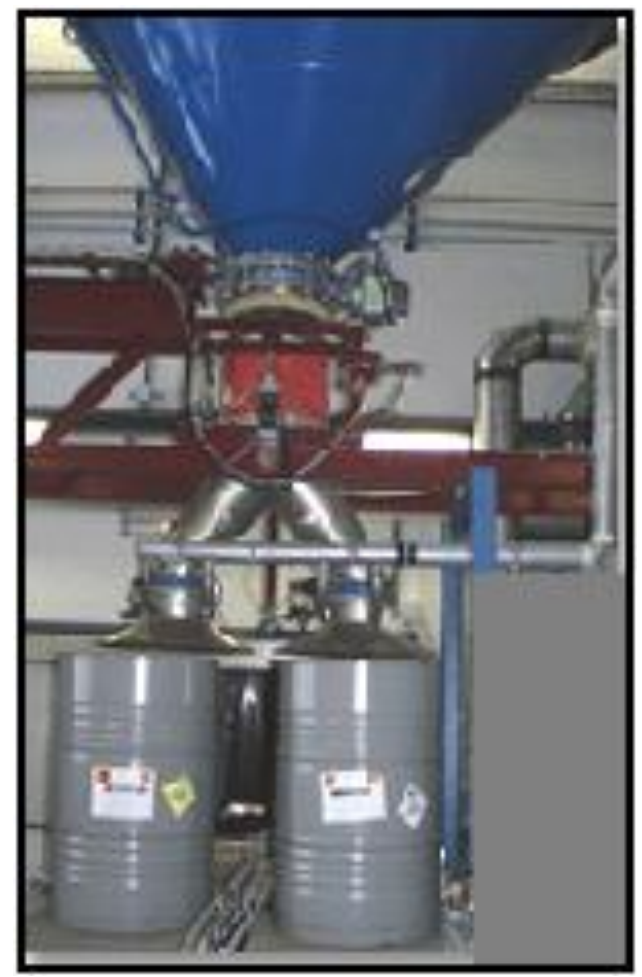

Fig. 5 Ammonium perchlorate crusher 


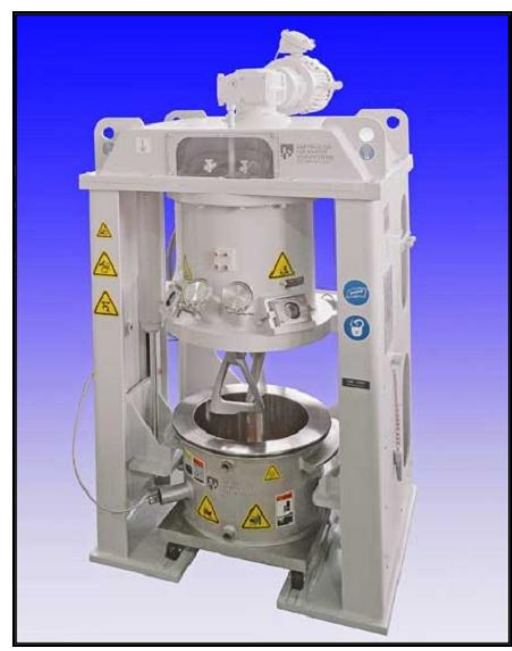

Fig. 6 Particle size analyzer

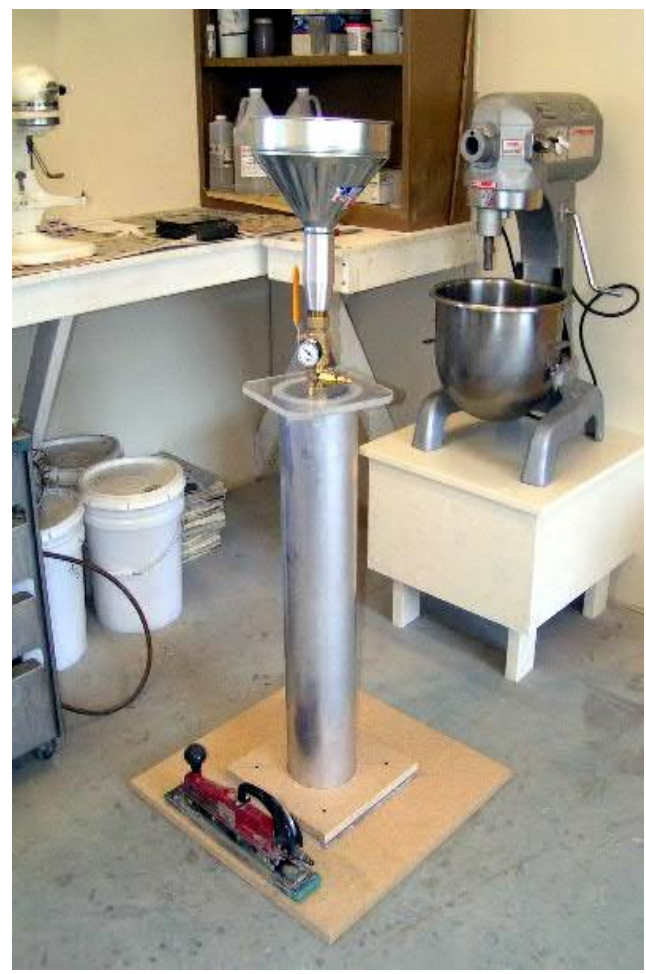

Fig. 7 Vacuum casting system 


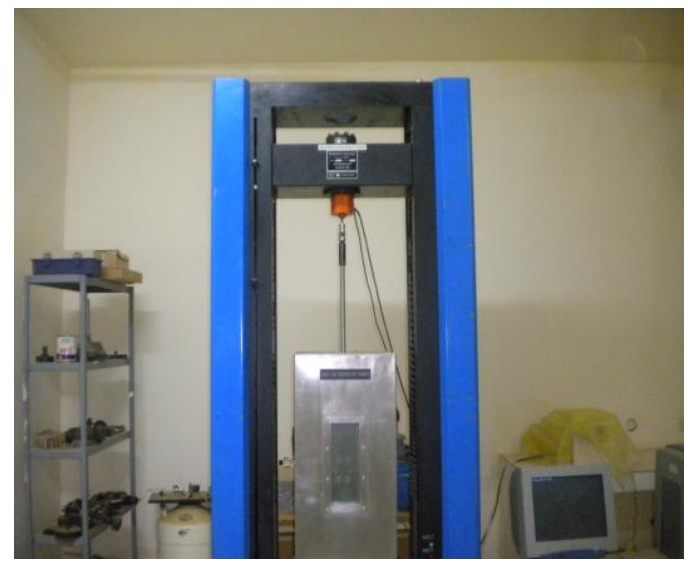

Fig. 8 5-Liter mixer

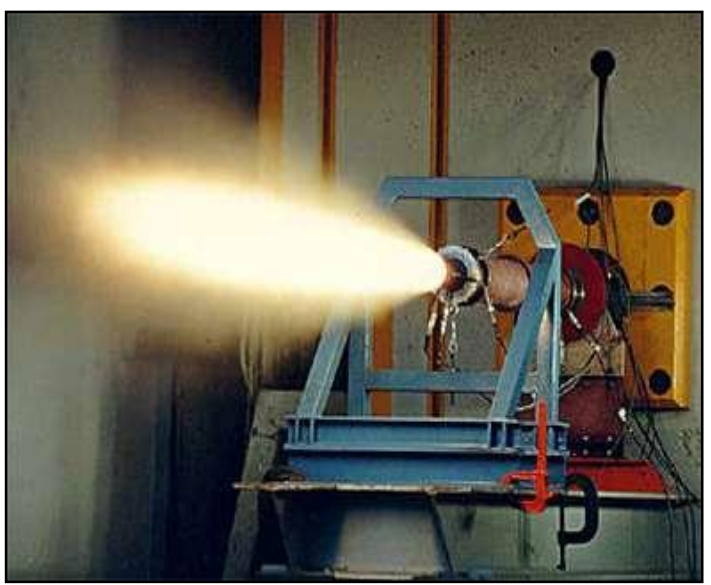

Fig. 9 Ground static testing device 